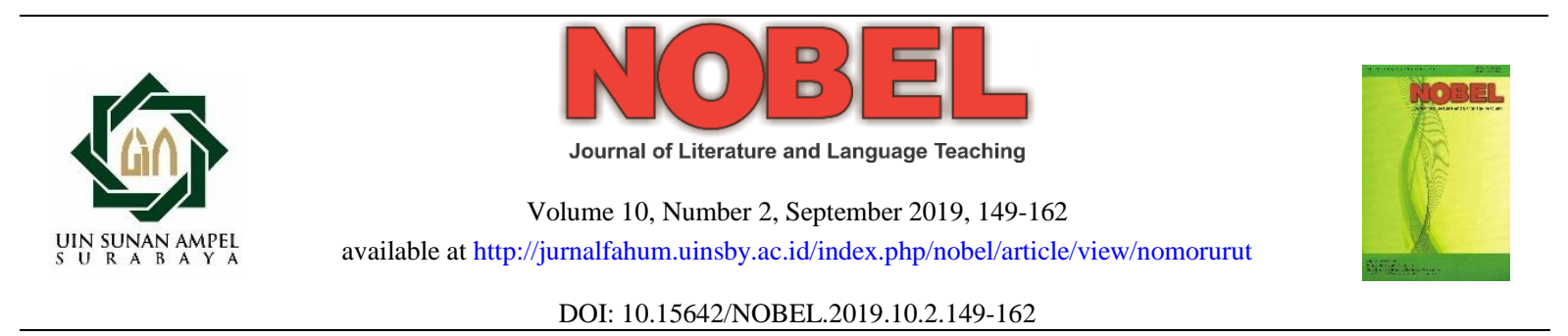

\title{
INTEGRATING ISLAMIC VALUES INTO ESP READING MATERIAL
}

\section{Pryla Rochmahwati ${ }^{凶}$}

IAIN Ponorogo, Jl. Puspita Jaya Pintu, Krajan, Jenangan, Ponorogo, East Java 63492.

\begin{tabular}{l}
\hline Article Info \\
\hline Article History: \\
Received January 2019 \\
Accepted August 2019 \\
Published September 2019 \\
\hline Keywords: \\
Islamic Values, ESP \\
Reading Material \\
\hline
\end{tabular}

\begin{abstract}
This present research is aiming at developing suitable instructional reading material for the students of Islamic Education Department. The procedure employed in this study was $R \& D$ model proposed by Dick and Carey, namely, need analysis, developing reading materials, expert validation, revising the materials, trying out the materials, and revising the materials. The result shows that reading materials must be developed by incorporating major content subject, namely Islamic studies, list of vocabulary, grammar review, and reading comprehension exercises. Furthermore, after being tried-out, it shows the applicability of the developed materials in helping the students to accomplish the mastery of reading skills and improve their learning motivation. In spite of the strength of the material developed, it is still tried-out in the small scale; therefore, the materials were still possible to be revised.
\end{abstract}




\section{INTRODUCTION}

The main reason for students in university to learn English is to help them acquire information in their field of study through textbooks, articles, lecture notes, technical instructions, and others. Many students want to be able to read texts in English either for their careers, for study purposes or simply for pleasures (Harmer, 2002:45).

Learning materials are often the most significant and observable component of pedagogy. They determine the quality of language input and language practice during the learning process in the classroom. Richards (2001) stated that materials in language teaching have roles as a resource for the presentation of materials either spoken or written and as a source of activities for learners' practice. Therefore, the lecturers are obliged to develop teaching materials which are suitable for the students' need and always up-to-date.

In the academic field, especially in higher education, reading plays an important role to learn a certain message contained in their textbooks, article, report, etc. Since, reading is an interaction between the reader and the text requiring a rich background and adequate knowledge of language (Grabe, 2002), selecting a reading text for student is essential in the learning of reading. Furthermore, Alderson (2000) regarded reading as a complex process affected by such variables as a reader (including knowledge, skills, abilities, motivation, affect, and other characteristics of the reader) and text (for example, topic and content, type and genre, text organization. Therefore, a textbook in English for university students is one essential factor to help them learn English well, particularly reading skill.

Considering the important position of English in the curriculum of Tarbiyah and Teacher Training Faculty of IAIN Ponorogo, the materials of reading comprehension for the students of will be chosen as the ones to be developed in this study. Through reading the students are exposed to learn the aspects of language such as vocabulary, grammar, punctuation, the way sentences, and paragraph are constructed and texts. Besides they are expected to be able to do a number of things with a reading text, like to scan the text for particular bits of information they are searching for or to skim a text to get a general idea.

Some research revealed the importance of developed materials for engaging students' achievement and motivation during the teaching and learning process. Usadiati (1999) developed a model of ESP reading Materials for the Extension Program at the Faculty of Agriculture, Brawijaya University. The finding showed that the materials were developed based on the content-based approach and it was proven that students seemed to have higher motivation and interest in reading English textbooks and journals when the model of ESP reading materials since the developed textbook was suitable to the students' need. The similar 
research was conducted by Hanifah and Afidah (2018) which aims at developing reading textbook for Sharia Economy students which employed Reading Strategy Based Instruction. The result showed that students in Sharia Economy major were interested in learning English since the subject is related to their need and major. Referring to the previous research above, the researcher can conclude that reading materials development has gained utmost attention in research. However, there was no researcher who integrates Islamic values into the reading materials for Islamic Education Major. Harahap (2015), however, has developed reading material for junior high school students in the form of textbook containing precious Islamic stories. The textbook is completed by reading technique, some exercises of reading skill and vocabulary in every chapter. The topics in the textbook are all about Islamic stories.

The National Qualification Framework (KKNI) curriculum of IAIN Ponorogo (2015) stated that foreign languages, especially Arabic and English are very important for the students to prepare them communicating in those languages, even for non-English Department. Referring to those, English is one of the foreign languages offered to students so that they can communicate in English. The total credit for English subject is 4. The teaching of English in Tarbiyah and Teacher Training Faculty of IAIN Ponorogo has a number of problems that need to be taken into account. The main problem is that an appropriate English subject material for students was not available. The materials used currently integrate a lesser amount of Islamic values and do not match the needs and characteristics of the students.

The researcher found in the preliminary observation that the materials for Bahasa Inggris course used today have not undergone any changes in terms of the material development for the last ten years and were only compiled by the lecturers at Islamic Education Department of Tarbiyah and Teacher Training Faculty at IAIN Ponorogo. The compilation of the materials is usually in the form of texts or passages taken from any sources which frequently integrate a lesser amount of Islamic values that refer to their own content subject. The instruction process using the existing material has some weaknesses namely: (1) the instruction is not proceeded by an effort to attract the students' interest; therefore, it does not quite encourage the students to learn, (2) the instruction does not begin with the instructional objective, (3) the instruction tends to be so monotonous and focused more on grammatical task that the students lose their interest to learn and, (4) the instruction cannot obtain a maximum result due to the limitations of the available material.

Regarding the problems mentioned, something has to be done to change the unfavorable situation into a better one by developing materials as a source of learning and an alternative to cope with the problems of learning English at IAIN Ponorogo, by considering the needs and 
characteristics of the students. Materials play a very important role that they determine the success of any teaching and learning process.

For those aims, the students of Islamic Education Department of Tarbiyah and Teacher Training Faculty of IAIN Ponorogo need appropriate reading materials for Bahasa Inggris course that meet their needs. Richard (2015) found that particularly the main problem encountered in the non-English department is the lack of suitable instructional materials relevant to the specific English needs. One way to resolve the problem is to develop a learning package which fulfills the students' requirement in terms of quality and attractiveness of the teaching materials. The students need materials which integrate their content subject namely Islamic studies with the language they are studying. The integration is intended to develop academic knowledge and skills of the students in their major content subject/Islamic values while they acquire the academic language needed to succeed in the university level.

The aim in conducting this study is to develop suitable reading comprehension materials in Bahasa Inggris course which integrate Islamic values for the students of Islamic Education Department of Tarbiyah and Teachers Training Faculty IAIN Ponorogo. The development produced an English textbook that is relevant to the objective of the curriculum and the needs of the students. It is expected that the lecturers and the students can take advantages of the product of the development.

\section{REVIEW OF LITERATURE}

Cognitive psychologists regarded reading as an internal process that requires readers to build a conceptual model from the text and perceptible hints outside of the text (Grabe 2009; Kintsch 2004; Zwaan and Rapp 2006). It implied that reading consists of two related processes: word recognition and comprehension. Word recognition refers to the process of perceiving how written symbols correspond to one's spoken language. Comprehension is the process of making sense of words, sentences and connected text. Readers typically make use of background knowledge, vocabulary, grammatical knowledge, experience with text and other strategies to help them understand written text.

Reading every word of a text is not always necessary in the reading activity. Spending too much time on individual words can distract one's understanding of the text being read. In addition to the strategies, the reader uses to make sense out of point, successful readers also reading skills (Gebhard, 2000). Students need to be able to do a number of things with a reading text. So it is clear that skills of reading comprehension are a set of skills which the 
reader to deal with reading text. According to Alexander (1998), skills of reading comprehension include (1) finding the main ideas, (2) remembering details, (3) recognizing sequence, (4) following direction, (5) summarizing and organizing information, (6) generalizing, and (6) predicting outcomes.

\section{English for Specific Purposes}

English for Specific Purposes (ESP) is driven by the specific learning needs of the language learner. When designing an ESP course, another issue to take into consideration is that grammatical functions, acquisition skills, terminology, specific functions of discipline content are crucial parts of the ESP course.

ESP is language teaching given to the students who professional study and job-related reason in that English is used in common context or in the context of the students' subject area. The aim of the ESP program is to develop the linguistic potentialities of the students who need the language to update knowledge in their specialties (Budianto, 2003). Furthermore, Hutchinson and Waters (1987) stated that with ESP, all decisions on content and method are based on the learners' language needs, which according to Johnson cited in Jiajing (2017), refer to the language components that a group of learners from a certain discipline should know and the language skills they should be equipped with no function effectively in that discipline. In line with this, Orr (2017) states that ESP is driven by the specific learning needs of the language learner.

\section{Material Development}

Borg and Gall (1983) state that material development has its root in the strategy for developing the educational product of proven effectiveness which is called educational research and development or sometimes it is contracted into $\mathrm{R} \& \mathrm{D}$. Concerning the development of reading materials, it should consider the students' need and background knowledge. Moreover, the reading materials also should suit the level of the students and offer a variety of exercises (Ellington, 1985). Tomlinson and Masuhara (2004) also state that materials should be developed in ways which provide flexibility of use as well as coherence of connection. Furthermore, Nunan (1988) states that reading materials should be graded from easy to more difficult materials.

Some models of developing instructional materials are proposed by experts of instructional design, namely Tomlinson, Richards, Dick and Carey, Finney, and Hyland. According to Tomlinson (1998), there are seven steps in the process of materials writing. The steps are the identification of need for materials, exploration of need, the contextual realization of materials, pedagogical realization of materials, production of materials, student 
use of materials, evaluation of materials against agreed objectives. In addition, Richards (2001) points out that curriculum development processes in language teaching comprise needs analysis, goal setting, syllabus design, methodology, testing, and evaluation. Dick and Carey (1990) propose a model of instructional design which is called a systematic instructional design. They offer ten steps i.e. identifying instructional goals, conducting instructional analysis, identifying characteristics of the students, writing performance objectives, developing test-items, developing instructional strategies, developing instructional materials, conducting formative evaluation, revising instructional materials and conducting summative evaluation.

Correspondingly, Finney (2002) describes a framework of instructional materials development consisting of four stages of decision making. The stages are curriculum planning, ends/means specification, program implementation, and implementation in the classroom. She, however, believes that evaluation is not a stage in itself, but as necessary and integral part of each and all of the stages already mentioned. Hyland (2003) suggests nine steps of materials development related to course materials, namely: consideration of the students (personal goals, proficiency levels, interest, etc.), consideration of learning context (duration, resources, relationship to other subjects), consideration of the target context (future roles of learners and the text and the tasks they need), establishment of course goals and objectives, planning the syllabus, devising units of work and lessons, creation or evaluation and selection of materials, teaching the course, evaluation of learners.

All models might be applicable and well employed in developing language instructional materials. However, it is possible to make some modifications in the model of syllabus/materials development to suit particular instructional needs, purposes, and available resources.

\section{Integrating Islamic Values into Reading Materials}

The integration of Islamic values in all lessons, including foreign language, is essential due to the role of Muslim in preserving the religious values through their classroom activities (Rohmah, 2012). Also, the linguistic reasons suggest the teachers accomplish these efforts in their classrooms as what Johnston (2003) said that, like the essence of all teaching, the essence of language teaching lies in values. It means that, when foreign language instruction is blended with religious values, the pedagogic goal of teaching will keep being achieved.

The English language curriculum, especially reading, can promote an appreciation for, and development of, Islamic values by integrating Islamic elements into the lessons. The first word of the Holy Qur'an that was revealed to Prophet Muhammad (peace be upon him) is 
"READ" which is also a command of Allah (SWT). This condition indicates the importance of reading, a skill that is required in all disciplines. We should, therefore, instill in our students a love for reading, and provide them with meaningful and morally appropriate material. This can be achieved by incorporating Islamic selections, like biographies of important Muslims, both past and present. Many of these biographies can be accessed via the internet. Biographies of the prophets of Allah, especially Prophet Muhammad (peace be upon him), Muslim women, will demonstrate to students the high value placed on moral character, noble conduct, and hard work, and provide students with Islamic role models.

In conclusion, it can be said that the integration of the Islamic values with the teaching of English will make Muslim students have a more comprehensive understanding of their religious teaching, especially something related to seeking knowledge.

\section{METHOD}

As this research deals with the development of reading comprehension materials, the design of this research is categorized into research and development (R\&D). According to Borg and Gal (1983), R\&D is a process used to develop and validate educational products. The products of $\mathrm{R} \& \mathrm{D}$ can be textbooks, audiovisual materials, training manual, equipment, and many others. Concerning the aim to be reached in this study, the final product of this study is a textbook namely reading comprehension material in "Bahasa Inggris" course for the students of Islamic Education Department of Tarbiyah and Teacher Training Faculty at IAIN Ponorogo.

The procedure being employed in this study was adopted by $R \& D$ model proposed by Dick and Carey (1990), namely, need analysis, developing reading materials, expert validation, revising the materials, trying out the materials, and revising the materials. To do the need analysis, the researcher distributed questionnaires to the students and interview to the colleague lecturer. Some questionnaires are also given to expert in reading instruction, content, Islamic values. Some criteria are raised in the questionnaire in terms of the clarity of the instructions, relevance of the difficulty level, presence of Islamic perspectives, the effectiveness of content to meet curriculum requirements, and the variety and purposefulness of learning activities. Furthermore, the expert of the textbook layout was given questionnaire in terms of the consistency of layout with appropriate use of space and margin for ease reading and the suitability of print font size and type. 


\section{RESULTS AND DISCUSSIONS}

\section{The Result of Need Analysis}

Based on the result of the questionnaire distributed to the students and the result of the interview conducted with the lecturers, the researcher found that most of the students agree $(85.76 \%)$ to develop reading materials which are suitable with their major content subject namely Islamic Education.

According to the result of an interview with the chief of Islamic Education Department and lecturers, the reading materials for the students of Tarbiyah and Teachers' Training Faculty, IAIN Ponorogo Department, ought to be focused on the texts which have relation to Islamic studies. The statement is with the consideration that to make the materials more interested and the students become more motivated to learn them as well as to make the learning more effective.

Furthermore, the data indicated that the students agreed $(78.5 \%)$ to include a list of vocabulary in the reading materials developed. These responses are in line with what the lectures stated in the interview. The lectures also suggested to provide the students with a list of vocabulary based on the text they are concerned with so that they can memorize and use the vocabulary, especially those that are related to technical terms in their major content subject, and finally they can understand the text easily.

Besides the findings above, the data on the questionnaire $77.9 \%$ students also demonstrated that the future reading materials should include grammar review. In the students' opinion, the grammar review was necessary to include in the materials because they expect to be able to understand the rules of English language such as how to write good sentences, how to use particular tenses, how to make passive sentences, and so on.

Another data also indicated that the materials should be arranged according to the degree of their difficulty. $81.63 \%$ students stated their agreement about this. They had the reason that the materials need to be compiled based on the level of their difficulty so that they can learn the materials easier and more systematic. In line with the above findings, the result of the interview showed that the lecturers agreed with the students' opinion.

\section{Draft of Material Development}

Taking the result of the needs analysis into consideration, the first draft of the material was developed. The materials were developed in the form of a textbook containing reading texts and tasks designed for the first semester students of Islamic Education Department at IAIN Ponorogo. The materials in the textbook were developed to provide the students with the knowledge of comprehending Basic English to introduce them the English grammatical 
structures. Besides, the materials were intended to enrich the student's knowledge in their field of study.

The materials are divided into 12 units based on the three main topics, namely, Aqidah, Syari'ah, and Fiqh. The subtopics for 12 units are (1) The Core Religious Practice of Islam: The Five "Pillars" of Islam, (2) The Witness to Faith, (3) Shalah, (4) Zakat (5) Health Benefit of Fasting, (6) Eid Fitr and Eid Adha, (7) Muslim Culture \& the Style of Hijab, (8) Six Articles of Faith, (9) Belief in Allah: the First Article of Faith in Islam, (10) Believe in the Angels of Allah: the Second Article of Faith , (11) Belief in Allah's Books: The Third Article of Faith, (12) Sharia: the Path of Allah. Each section contains texts which involve items such as comprehension questions, vocabulary tasks, grammar reviews, and grammar tasks.

\section{The Result of Expert Validation}

From the evaluation done by the reading instructional expert, it was found that the draft of the materials which had been developed had some good (strengths) and bad points (weaknesses). The good points related to the physical appearances of the materials, the organization of the materials and the instructional objectives on the materials and the suitability of the materials with the comprehension questions, the grammar reviews, and the tasks. Besides the good points described above, there were some bad points the expert identified on the materials, which need to be revised. It deals with the formulation of the instructional objectives, the suitability of vocabulary list, the use of complex language and the existing of complicated structures in the text.

The expert of the content of reading material suggested some aspects be revised such as the clarity of instructional objectives and the appropriate arrangement topics presented in the textbook. Another important comment and suggestion given by the content expert were related to the content of the materials. He thought that the content of the materials was good in general especially the selection of the materials in which the students were expected to be able both to increase knowledge in their field of study and improve their English.

The expert of Islamic values identified some good points in terms of topics presented on the draft. They were interesting, various, up-to-date, appropriate to the needs and interest of the students, and relevant to the content subject of the students in which it has to integrate Islamic values on the text, yet most of which need to be rearranged.

According to the expert of layout design, the good points of the draft were related to the physical appearances of the materials: cover design, letters, typing, spacing, and layout of the materials. It is attractive, clear, neat, and consistent. However, the developer still needs to highlight important keywords in the text with different font and color. 


\section{The Result of Try out The Developed Materials}

The result of questionnaires distributed to the students and the colleague lecturer is discovered in this section.

Dealing with the cover design, letters, typing, spacing, and layout of the materials, the students and the lecturer had the same opinion that they were attractive, clear, neat, consistent, and appropriate. In terms of the organization of the materials, both the students and the colleague lecturers agreed that it was attractive and the organization of the materials was logical in terms of tasks order.

Regarding the topics, list of vocabulary, and the texts presented on the draft, the students found that the topics were interesting, various and up-to-date since they were appropriate to their needs and interest and relevant to their content subject. Concerning the comprehension questions, the grammar reviews, examples and the tasks, both the students and the lecturer stated that the comprehension questions were comprehensible, appropriate, and they provided support to the comprehension of the texts.

Concerning the instructional directions, the coverage of the materials, and the content of the materials, the students and the lecturer had the same opinion that the directions were clear, appropriate, and comprehensible. The clarity of the instruction that precedes each task helped the students follow and do the tasks on the material. The coverage of the materials according to the students was relevant and suitable to their needs and interest. Besides, the lecturer considered that the coverage of the materials had represented the aspects which could help the students develop their reading skill. About the content of the materials, both the students and the lecturer considered that the content of the materials was clear, relevant, and suitable.

Finally, it can be said that the materials were quite applicable in terms of the level of difficulty, usefulness, effectiveness, and attractiveness for the students of Islamic Education Department at IAIN Ponorogo. Furthermore, the materials were still possible to be revised if some weaknesses are found in its actual implementation.

\section{Discussion of the Findings}

This part presents the discussion of the findings of the research presented before. According to the observation that was done in the early stage of this research study, it was found that students of Islamic education Department needed English reading materials which focused Islamic values content, vocabulary items, and grammar. The materials developed are expected to overcome the present problem at IAIN Ponorogo namely lack of suitable materials which hopefully can improve the proficiency of the students in reading. 
The needs analysis was conducted to gather the information from the learners and the teacher in terms of learners' profile (Graves, 2008) goal and procedures (Nunan, 1988). The data obtained from the need analysis then were used as the basis of designing the units in forms of English reading materials for students of Islamic Education Department. Due to the fact that the students required to learn English in order to help them acquire information in their field of study as principles of ESP (Hutchinson and Walters, 1991) and material development (Dick and Carey, 1990) were applied to design the materials that were appropriate to the students' needs.

The developed English reading materials met one of the criteria of materials pointed by Day (1994) in terms of interest, readability, exploitability, topic, and appearance. Furthermore, the role is focusing on understandable, relevant, and interesting exchanges of information, rather than the presentation of grammatical form.

The first draft of the developed materials then was consulted to the expert of reading instruction, content, Islamic values, and layout design. It was found that there are some good and adverse points of the developed materials. The researcher had to revise the bad ones. To support the expert's judgment on the developed materials, pre-test, try-out, and post-test were conducted. The data collected from observation shows that the students actively involved in the teaching and learning process during the try-out. One of the reasons is that the topics being discussed are interesting and it related to Islamic values as the major content subjects of the students. The result of try-out of the developed materials shows the applicability of the developed materials in helping the students to achieve the mastery of reading skills and improve their learning motivation.

After conducting the try-out, a form of empirical evaluation questionnaire which consisted of 10 statements related to the clarity of the instructions, relevance of the difficulty level, presence of Islamic perspectives, the effectiveness of content to meet curriculum requirements, and the consistency of textbook layout was distributed to the students in order to measure the actual effect of the tried-out materials on the students. The result showed that $87,52 \%$ and $79,25 \%$ students stated that the instruction is very clear and it was arranged following the level of difficulty respectively. Then, it was found that most of the students agreed $(86.78 \%)$ the reading materials are suitable for their major content subject.

Five components of the developed materials were evaluated by using theory proposed by Tomlinson and Masuhara (2004), and the designed materials were approved to be suitable for Islamic Education Department. Finally, the materials were still possible to be revised if some weaknesses are found in its real implementation. 


\section{CONCLUSION}

It is necessary to develop English reading materials which are suitable for students of Islamic Education Department. Therefore, this study aims at developing English reading materials for students of Islamic Education Department of Tarbiyah and Teacher Training Faculty at IAIN Ponorogo. By considering the objective of this study, the researcher made two deductions in terms of the process in developing the materials and on the specification of the product.

Regarding the process in developing the materials, there were several phases the material developer should follow, i.e; conducting need analysis, developing material blueprint, organizing the materials, judging the designed materials by employing expert judgment on reading instruction, content, Islamic values and layout design, trying out the second draft, evaluating and revising the materials, and writing the final draft of the designed materials.

In terms of the specification, the materials were divided into 12 units based on the three main topics, namely, Aqidah, Syari'ah and Fiqh. The subtopics for 12 units are (1) The Core Religious Practice of Islam: The Five "Pillars" of Islam, (2) The Witness to Faith, (3) Shalah, (4) Zakat (5) Health Benefit of Fasting, (6) EidFitr and EidAdha, (7) Muslim Culture \& the Style of Hijab, (8) Six Articles of Faith, (9) Belief in Allah: the First Article of Faith in Islam, (10) Believe in the Angels of Allah: the Second Article of Faith , (11) Belief in Allah's Books: The Third Article of Faith, (12) Sharia: the Path of Allah. Each section contains texts which involve items such as comprehension questions, vocabulary tasks, grammar reviews, and grammar tasks.

In spite of the strength of the material developed, however, the material is not tried-out in the large scale, and they are not accompanied with enrichment for more able students and remedial for the less able students. Therefore, the materials were still possible to be revised.

\section{REFERENCES}

Alderson, J. C. (2000). Assessing reading. Cambridge: Cambridge University Press.

Alexander JE. (1998). Teaching reading. Boston: Scot, Foresman, and Company.

Borg., M. Gall. D. (1983).Educational research: An introduction. New York: Longman, Inc.

Budianto, L. (2003). Developing the English syllabus for the students of nursing academy in Muhammadiyah university of Malang. Unpublished Thesis. Malang: Graduate Program in English Language Education State University of Malang

Day, R.R. (1994). Selecting a passage for the EFL reading class. English Teaching Forum, 32(1), 20-24. 
Dick, W., Carey, L. (1990). The systematic design of instruction. USA: Harper Collins Publishers.

Ellington, H. (1985). Producing teaching materials: A handbook for teachers and trainers. London: Kogan Page Ltd.

Finney, D. (2002). The ELT curriculum: A flexible model for a changing world. In Richards \& Renandya (Eds.), Methodology in language teaching: An anthology of current practice. Cambridge: Cambridge University Press. 2002from http:// www.jaltpublications.org/tlt/articles/20 02/07/grabe

Gebhard.J. (2000). Teaching English as foreign or second language. Michigan: The University of Michigan Press.

Grabe, W. (2002). Foundations for L2 reading instruction. The Language Teacher Online. Retrieved November 15, 2018, from http://jaltpublications.org/old_tlt/articles/2002/07/grabe

Grabe, W. (2009). Reading in a second language: moving from theory to practice. Cambridge: Cambridge University Press.

Graves, K. (2008). The language curriculum: A social contextual perspective. Language Teaching, 41(2), 147-181.

Hanifah., Afidah, N. (2018). Developing textbook by using reading strategic based instruction method for shariah economy department. Journal of English Educators Society, 3 (2), 155-164.

Harahap, R. (2015). Designing English reading materials for an extracurricular program of al-Munawwariyah islamic junior high school Muhammadiyah II Malang. Unpublished Thesis Malang: Malang Islamic University.

Harmer, Jeremy. (2002). The practice of English language teaching (3rd Edition). London: Longman.

Hutchinson, T., Waters, A. (1991). English for specific purposes: A learning-centered approach. Cambridge: Cambridge University Press.

Hyland, K. (2003). Second language writing. Cambridge: Cambridge University Press.

IAIN Ponorogo. (2015). The national qualification framework (KKNI) curriculum of IAIN Ponorogo. Ponorogo: IAIN Ponorogo

Jiajing, G. (2017) Designing an ESP course for Chinese university students of business. Retrieved Noveber 15, 2018, from http:// www. esp-world.info/index.html

Johnston, B. (2003). Values in English language teaching. Mahwah, NJ: Lawrence Erlbaum Associates.

Kintsch, W. (2004). The construction-integration model of text comprehension and its implications for instruction. Theoretical models and processes of reading, 5, 1270-1328.

Nunan, D. (1988). Principle for designing language teaching materials: Guidelines periodical for classroom language teachers. Institute for Education Science, 10(2), 1-24.

Orr, T. (2017). ESP for Japanese universities: A guide for intelligent reform university of Aizu. Retrieved November 5, 2018, from http://www.jaltpublications.org/tlt/files/98/nov/orr.html 
Richard, J.C.(2015). Developing speaking activities. From theory to practice. Retrieved February 14, 2015 from http://www.professorjackrichards.com/pdfs/developingclassroom-speaking-.

Richards, J. C. (2001). Curriculum development in language teaching. Cambridge: Cambridge University Press.

Rohmah, Z. 2012. Incorporating Islamic messages in the English teaching in the Indonesian context. International J. Soc. Sci. \& Education, 2(2), 157-165.

Tomlinson, B. (1998). Materials development in language teaching. Cambridge: Cambridge University Press.

Tomlinson, B.,Masuhara, H. (2004). Developing course materials: RELC Portfolio Series 11. Singapore: SEAMEO Regional Language Center.

Usadiati, W. (1999). Developing A model of ESP reading materials for team-teaching using content based approach. Unpublished Thesis. Malang: PPS UM.

Zwaan, R. A., \& Rapp, D. N. (2006). Discourse comprehension. Handbook of psycholinguistics, 2, 725-764. 